\title{
The Impact of Foreign Influence on Exporting through Open Innovation
}

\section{Piers Thompson}

Economics Department, $8^{\text {th }}$ Floor Newton Building, Nottingham Business School, Nottingham Trent University, 50 Shakespeare Street, Nottingham, NG1 4FQ, UK. piers.thompson@ntu.ac.uk

\section{Wenyu Zang}

Economics Department, $8^{\text {th }}$ Floor Newton Building, Nottingham Business School, Nottingham Trent University, 50 Shakespeare Street, Nottingham, NG1 4FQ, UK. wenyu.zang@ntu.ac.uk

\begin{abstract}
Foreign direct investment brings both increased competitive pressures and opportunities for domestic Small and Medium Sized Enterprises (SMEs). Competition may force them to seek new international markets, but also provide access to international customers. However, as economies become more knowledge based in order to access international markets SMEs must seek to innovate. This study examines how foreign firm presence and innovation influence the exporting activities of SMEs. It contributes to the existing literature by dividing innovation into product/process innovation and in-house/open innovation. With open innovation, products are more likely to be novel and productivity boosted to a larger degree. We interact different types of innovation with foreign influence to examine whether there is a moderating influence on the relationship. The individual firm level data and foreign influence data are from the Longitudinal Small Business Survey and Office for National Statistics. Whether firms are active exporters is explored using multilevel logit regressions. Both innovative activities and the foreign influence increase the likelihood of exporting. In-house product innovation boosts export propensity to a lesser degree in areas with higher levels of foreign influence. The hypothesis that open innovation has more impact on exporting activities when foreign influence is greater is not supported for either type of innovation.
\end{abstract}

Keywords: Foreign Influence, Exports, Open Innovation, In-house Innovation

Please cite this article as follows:

Thompson, P. and Zang, W. (2019) 'The Impact of Foreign Influence on Exporting

through Open Innovation', Growth and Change, doi: 10.1111/grow.12349

which has been published in final form at:

http://dx.doi.org/10.1111/grow.12349

This article may be used for non-commercial purposes in accordance with Wiley Terms

and Conditions for Self-Archiving. 


\section{The Impact of Foreign Influence on Exporting through Open Innovation}

\section{Abstract}

Foreign direct investment brings both increased competitive pressures and opportunities for domestic Small and Medium Sized Enterprises (SMEs). Competition may force them to seek new international markets, but also provide access to international customers. However, as economies become more knowledge based in order to access international markets SMEs must seek to innovate. This study examines how foreign firm presence and innovation influence the exporting activities of SMEs. It contributes to the existing literature by dividing innovation into product/process innovation and in-house/open innovation. With open innovation, products are more likely to be novel and productivity boosted to a larger degree. We interact different types of innovation with foreign influence to examine whether there is a moderating influence on the relationship. The individual firm level data and foreign influence data are from the Longitudinal Small Business Survey and Office for National Statistics. Whether firms are active exporters is explored using multilevel logit regressions. Both innovative activities and the foreign influence increase the likelihood of exporting. In-house product innovation boosts export propensity to a lesser degree in areas with higher levels of foreign influence. The hypothesis that open innovation has more impact on exporting activities when foreign influence is greater is not supported for either type of innovation.

Keywords: Foreign Influence, Exports, Open Innovation, In-house Innovation

\section{Introduction}

The relationship between foreign direct investment (FDI) and entrepreneurship (or small business practices) has been found to be highly complex. Although there are potential benefits from greater foreign influence in the local economy through technology and management spillovers (Fu, 2012), and increased demand for domestic production (Markusen 
\& Venables 1999), there are also potential negatives through competition in either the output or input markets (Girma, Greenaway, \& Wakelin, 2001; Martins 2011) and by attracting the most entrepreneurial individuals away from business ownership into corporate employment (Grossman, 1984). It is therefore understandable that empirical studies examining the relationship between foreign influence and entrepreneurship find a range of results (Ke, 2010; Liu, 2008; Thompson \& Zang 2015, 2018).

One particular relationship that is of interest is whether greater foreign business presence increases the export orientation of domestic businesses. Competition could weaken existing businesses limiting their export potential (De Backer \& Sleuwaegen, 2003), but an alternative is that serving a foreign customer gives domestic firms experience of international entrepreneurship (Barbosa \& Eiriz, 2009). Given the uncertainties caused by the decision of the UK to leave the European Union (EU) in the referendum of 2016 it is important to understand the influence of FDI in this area of domestic SME activity.

This study will look to examine how foreign firm presence influences the exporting activities of domestic SMEs. The study focuses on one particular mechanism where knowledge spillovers from foreign firms boost productivity allowing domestic firms to innovate and compete in international markets (Chen, Sheng, \& Findlay, 2013). This draws upon the concept of open innovation whereby firms access knowledge from other firms to innovate rather than developing products and processes entirely with existing internal resources and knowledge (Chesbrough, 2003). Understanding this relationship will help policy makers to fine tune policies relating to the attraction of FDI and support of export and growth efforts of SMEs in the correct fashion. 
In order to explore this relationship the study will utilise data from the Longitudinal Small Business Survey (LSBS) for 2015 and 2016 (Department for Business Innovation and Skills, 2016). This data is used to examine whether firms developing innovations are more likely to export or not. However, the influence of innovative activities is further examined by determining whether the innovation was developed with or without collaboration with other firms. To understand the impact of foreign firms in the local area (Local Enterprise Partnership) we interact open innovation with the level of foreign influence as measured by the presence of foreign firms as a proportion of all firms. This data is based upon the Office for National Statistics's (ONS) 'Foreign Ownership of Businesses in the United Kingdom Analysis' (Office for National Statistics [ONS], 2010). A multilevel regression approach is used to examine how this contextual factor influences the exporting activity of individual firms and whether there is a moderating influence on the relationship.

This study contributes to the existing literature by dividing innovation into product/process innovation and in-house/open innovation. Esteve-Pérez and Rodríguez (2013) find that both product and process innovation increase the probability of exporting, but they don't distinguish between in-house and open innovation. In addition, we interact different types of innovation and foreign influence to examine whether open/in-house innovation boosts export propensity to a greater/lesser degree in areas with higher levels of foreign influence.

The remainder of the paper is structured as follows. Section 2 explores the literature examining the relationships between domestic innovation, foreign business ownership, and exporting activities. This literature is used to develop the hypotheses that will be tested by the empirical work that is outlined in section 3 along with the data utilised. Section 4 presents the 
results of the multilevel regression analysis. These are discussed and conclusions drawn for policy and SME management practice in section 5.

\section{Literature Review}

There are large and growing literatures that examine both the relationship between FDI and domestic SME survival, creation, and growth (De Backer \& Sleuwaegen, 2003; Girma et al., 2001; Thompson \& Zang, 2018), as well that examining the determinants of exporting behaviour by SMEs (Greenaway, Sousa, \& Wakelin, 2004). Within this section we initially outline the relationship between FDI and domestic SME exporting behaviour, including how innovative activities may form an intermediate step (Chen et al., 2013; Girma et al., 2001). The second subsection covers the literature that has considered the concept of open innovation (Chesbrough, 2003). The final subsection brings together the existing literature on the exporting and innovation relationship (Love \& Roper, 2015). These are then used to develop a number of hypotheses to be tested using the methods outlined in section 3 .

\subsection{FDI and Domestic SMEs}

The relationship between FDI and entrepreneurship has been found to be highly complex. Although there are potential benefits from greater foreign influence in the local economy through technology and management spillovers (Acs, O’Gorman, Szerb, \& Terjesen, 2007; $\mathrm{Fu}, 2012$ ), and increased demand for domestic production (Markusen \& Venables, 1999), there are also potential negatives. Greater foreign influence in the local economy can negatively impact on domestic entrepreneurs and their businesses through competition in either the output or input markets, such as that for skilled labour (Girma et al., 2001; Martins, 2011). It can also weaken local enterprise as a whole by attracting the most entrepreneurial individuals away from business ownership into corporate employment (Grossman, 1984). 
One particular relationship that is of interest is whether greater foreign business presence increases the export orientation of domestic businesses. As noted above the competition for inputs in particular could have a negative influence by weakening existing businesses (De Backer \& Sleuwaegen, 2003). It is also possible that the positive demand effect could have a negative long term effect whereby domestic firms become reliant on the local demand from a single large multinational customer and do not seek out overseas alternative markets (Román, Congregado, \& Millán, 2011; Thompson \& Zang, 2018). However, an alternative is that by serving a foreign customer albeit through its affiliate in the local market it is giving domestic firms experience of international entrepreneurship (Barbosa \& Eiriz, 2009). By serving these foreign customers the firms are aided in overcoming the cultural differences that make entering foreign markets costly (Zucchella \& Hagen, 2012). Some studies argue that the costs of exporting include a large fixed component (Helpman, Melitz, \& Yeaple, 2004). If this can be overcome more easily by serving foreign affiliates in the local economy domestic small businesses may be better positioned to export to overseas markets.

A further argument is that as foreign firms are more technologically advanced, interaction with them will increase productivity and boost innovation (Girma et al., 2001), which will allow domestic SMEs to more effectively compete internationally (Chen et al., 2013). This is the key mechanism that this paper seeks to investigate. In order to understand the potential of this mechanism in more detail we first look at the literature exploring the concept of open innovation (Chebrough, 2003), where such interactions may be actively pursued.

\subsection{Open Innovation}


There is now an established literature that acknowledges that innovation rarely occurs in isolation (Huggins \& Thompson, 2017). Knowledge may flow from one firm to another unintentionally or intentionally. Theories such as the knowledge spillover theory of entrepreneurship (Audretsch \& Lehmann, 2005), provide an example of the former where uncommercialised developments in large established businesses are pursued by entrepreneurial individuals in the form of new ventures (Acs, Audretsch, \& Lehmann, 2013). With regard to intentional collaboration, the concept of open innovation has come to the fore (Chesbrough, 2003; Chesbrough, Vanhaverbeke, \& West, 2006). Dahlander \& Gann (2010) in their review of the literature argue that openness with regard to innovation has been interpreted in a number of different ways. They identify two dimensions that openness in studies can be defined on: inbound versus outbound, and pecuniary versus non-pecuniary. In the case of the former this reflects whether firms are seeking knowledge and resources to use in their own innovation or making their resources available to others (Gassmann \& Enkel, 2004; van de Vrande, de Jong, Vanhaverbeke, \& de Rochemont, 2009). In terms of pecuniary or non-pecuniary considerations this relates to whether information is being sold or bought in the market (Chebrough \& Crowther, 2006; Hu, McNamara, \& McLoughlin, 2015), or more collaborative/networking approaches are being used (Henkel, 2006; Laursen \& Salter, 2006). This dimension is likely to be a continuum rather than a binary choice. For example, Anderson, Dodd, \& Jack (2010), and Huggins \& Thompson (2017) examine the benefits to innovative activity of utilising strategic network ties developed in a calculative manner, and those more embedded in entrepreneurial networks. Although the former might be more common for younger firms (Jack, Moult, Anderson \& Dodd, 2010), more formalised contracted relationships running from $R \& D$ agreements to equity partnerships may begin to take over as firms develop (Goerzen, 2005; Grant \& Baden-Fuller, 2004). More complex arrangements, such as crowdsourcing, where a wider group rather than an individual are 
given responsibility for a task also exist, and work has considered whether such activities should be organised directly or through an intermediary (Bogers et al., 2019).

Through collaboration with others, firms can get access to knowledge that they are incapable of producing themselves (Sammarra \& Biggiero, 2008). This may be particularly important for SMEs who are regarded as inventive, but may lack the resources to commercialise these ideas (Lee, Park, Yoon, \& Park, 2010). Marques and Ferreira (2009) examining Portuguese SMEs find the formation of networks and partnerships key in creating innovative capacity. This is a recognition that firms when developing products are often working within systems and cannot produce new products without consideration of others (Huggins \& Johnston, 2009; Lechner \& Dowling, 2003). It is also likely that specific forms of tie may better provide access to the distinct types of knowledge required for different types of innovation. Knowledge for process innovations may require more embedded relationships with higher trust, whilst more diverse targeted strategic relationships provide access to the original information for product and organisational innovations (Huggins \& Thompson, 2017; Lawton Smith, Romeo, \& Virahsawmy, 2012).

In order to achieve innovative outputs it is normally assumed that more tacit knowledge is required (Nonaka, 1991). As such knowledge is normally assumed to require geographical proximity for transfer to occur (Desrochers, 2001), the inference is that open innovation is most likely to occur in clusters of firms in particular geographical locations (Maskell \& Lorenzen, 2004). Others have suggested that with communication technology improvements the role of proximity may be altered (Wu, Kao, \& Shih, 2010). For less traditional nonhierarchical collaborative relationships information communications technology (ICT) can 
help coordination between firms and individuals (Bogers et al., 2019; Scuotto, Santoro, Bresciani, \& Del Giudice, 2017).

Increasing globalisation has allowed labour to become even more specialised, which can mean that companies can seek input into particular phases of their innovation processes from different locations (Dahlander \& Gann, 2010). Reliance on tightly bonded local networks has the danger of providing access only to a limited pool of knowledge with links to more distant sources often vital for innovation (Rallet \& Torre, 1999). This means that access to both local buzz and global pipelines becomes important for gaining access to a more diverse pool of knowledge whilst working in close collaboration (Bathelt, Malmberg, \& Maskell, 2004). Although ICT as noted above allows access to more geographically distant knowledge, in combination with increasing globalisation this has led to a more dynamic competitive situation where innovation is more important than ever (Scuotto, Santoro, Bresciani, \& Del Giudice, 2017). However, the quantity, complexity and tacit nature of much of the knowledge required ensures that geographical proximity, allowing face to face interactions, remains important (Acs, Audretsch, \& Lehmann, 2013; Huggins, Johnston, \& Thompson, 2012; McCann, 2008). Accessing diverse knowledge bases far from a firm's existing knowledge is costly, and may beyond a point lower innovation performance (Katila \& Ahuja, 2002). For SMEs in particular this fits with the findings of studies such as Fritsch \& Schwirten (1999) who highlight to the role of institutions such as universities as "knowledge aerials" for their local areas whereby global pipelines are accessed, but the knowledge is adapted for use by SMEs in the local environment.

In terms of the partners that are most effective it is found that customers and suppliers are the most effective and commonly used by SMEs for open innovation purposes (Vahter, Love, \& 
Roper, 2014). Working with universities and researchers may be more problematic given cognitive distances between the parties involved that may require a higher level of absorptive capacity to utilise such ties successfully (Maurer \& Ebers, 2006).

\subsection{FDI, Open Innovation and Exporting Activity}

Innovation is obviously seen as a key method for firms to gain a competitive advantage (Marques \& Ferreira, 2009). For the newest firms Eftekhari and Bogers (2015) note how open innovation could be highly important for their survival by overcoming the liabilities of newness. It is therefore a source of growth, although different types of innovation might be more closely associated with different types of growth. For example, employment growth is linked to radical product innovation, whilst process innovations are linked to sales growth for SMEs in Scotland and Northern England (Freel \& Robson, 2004).

More innovative firms are expected to take market share from non-innovators and be more productive (Hall, Lotti, \& Mairesse, 2009). This greater productivity is important with regard to exporting as it allows firms to overcome the fixed costs of exporting (Wagner, 2007). As such, as described above this implies that those firms that are engaged in innovation whether it is process innovations boosting productivity, or product innovations generating new demand for goods will be better placed to compete in international markets (Chen et al., 2013). Therefore, the literature seems to be in agreement that innovation may increase the likelihood of exporting:

H1: SMEs that have introduced innovations in the last three years will be more likely to export. 
Although the literature has suggested that innovation is to a greater extent taking the form of open innovation in recent years, less work has examined whether open innovation has a stronger effect on export propensity. Arguments that open innovation will draw on more diverse sources of knowledge, allowing for more radical innovations, might suggest that products are more likely to be novel in both national and international markets and productivity boosted to a larger extent. This might lead to the expectation that open innovation will boost export propensity to a greater degree than traditional innovation carried out in isolation:

H2: Innovation conducted in collaboration with other firms has a greater effect on export propensity than that conducted in isolation.

Any interaction between the innovation-export relationship with foreign influence is potentially more complicated. As outlined in subsection 2.1 competition for resources could weaken domestic SMEs (De Backer \& Sleuwaegen, 2003; Girma et al., 2001; Martins, 2011). This might restrict SMEs to pursuing either innovation or export ambitions rather than both. Equally, even positive demand effects may potentially lead to domestic SMEs focusing on serving a single local foreign owned client (Román et al., 2011; Thompson \& Zang, 2018). This could be to the detriment of exploiting export markets. Innovation may be sought to align with that of its main multinational customer rather than the wider market. By not competing knowledge flows will be more acceptable to foreign firms (Kneller \& Pisu, 2007).

Set against the negative possible relationships outlined above another alternative exists linked to the findings of studies such as Esteve-Pérez and Rodríguez (2013) who when examining Spanish SMEs find a bi-directional relationship with exports both boosting and being boosted by R\&D. Although such literature that acknowledges this bi-directional relationship adds 
much greater complexity in interpreting the results of empirical studies (Love \& Roper, 2015), it might help provide an explanation of how foreign influence will play a role. As outlined above innovation may help with initiating exporting activities, however, once firms are exporting, performance may also be improved through a number of mechanisms (Love \& Roper, 2015). In international markets firms will face more competition forcing further improvements in productivity. They may also spread the fixed costs of R\&D over a larger number of sales making innovation more attractive. Importantly for the focus of this paper, firms may also now gain access to new knowledge allowing them to improve innovative activities (Golovko \& Valentini, 2011). Where foreign influence is greater in the SME's domestic market the firm has potential access to such international knowledge when innovating initially, particularly where collaboration already occurs with foreign affiliates. Examining the source of export and innovation outcomes, Lecerf (2012) finds that French SMEs achieve more where they have greater technological resources already. This would further confirm the potential benefits of moving towards the technological frontier through working with more productive foreign affiliates in the local area (Acs et al., 2007).

The potential positive and negative interactions that can be drawn from the literature mean that the outcome is less clear. With in-house innovation the benefits of learning from international clients is reduced, therefore the negative interaction from reduced resources and reliance on single large clients might be expected to dominate.

H3a: In-house innovation will boost export propensity to a lesser degree in areas with higher levels of foreign influence. 
However, the potential to internationalise products where open innovation is conducted in an environment with plentiful sources of foreign owned businesses locally might promote the positive international knowledge-innovation-export mechanism outlined above.

H3b: Open innovation will boost export propensity to a greater degree in areas with higher levels of foreign influence.

Separately work has considered the impact of collaboration on innovation, the benefits of knowledge spillovers from FDI, and the relationship between innovation and exporting. Until now the three have not been regularly considered together. This study seeks to fill this gap in knowledge. The data and methods used to examine this are now discussed in the next section.

\section{Methodology}

\subsection{Longitudinal Small Business Survey}

The data utilised in this study is drawn from the LSBS for 2015 and 2016 (Department for Business Innovation and Skills, 2016). This is a survey conducted by the UK Government with the intention of providing a longitudinal data source for examining small businesses. The survey was stratified according to three dimensions, these being the four UK nations, firm size based on employment, and industry sector. In the case of the first dimension this was to obtain proportions of respondents equating to the underlying population of businesses in the four nations of the UK and a boost in Northern Ireland to ensure a sufficiently large subsample is obtained. In terms of firm size, proportions are intended to reflect the proportions of employment in these firms rather than the number of firms of each size. This included firms with zero employment and for these smaller firms, both those registered as companies and those that are not are included. Finally the sample is stratified on the basis of 14 one digit standard industrial classification (SIC) 2007 categories. Large businesses with 
250 or more employees, public sector companies and dormant or holding companies with zero employees and employment are excluded.

From the above 15,502 interviews were conducted in 2015 followed by 7279 in 2016, although a further 1969 top up interviews were conducted to maintain sample size in future years. As the focus is on exporting activity we excluded the construction industry as construction SMEs have less opportunity to export, producing a large negative coefficient on the dummy representing these firms. Estimates were generated for all results using the full sample and were qualitatively similar to those presented here excluding the construction industry. For this study the dataset provides individual firm level data for 5142 businesses where all required information is present in 2015 and 2016.

\subsection{Measures of Exports}

It has been suggested by some studies that exporting reflects two decisions, the choice to export in the first place, and once deciding to export, the extent of this exporting activity (Bernard \& Jensen, 2004). As most firms in the UK do not export any of their output we concentrate on this initial choice to export. The low level of exporting activity is suggested to reflect relatively high fixed costs associated with acquiring relevant information and knowledge about export markets (Chen et al., 2013). As discussed in the preceding sections it is access to this knowledge that is likely to spillover through cooperation and interaction with foreign firms (Kneller \& Pisu, 2007).

In the LSBS two items are included considering the percentage of turnover accounted for by exports of goods or services respectively. These were used in combination to identify those firms that exported at least some of their turnover in the form of goods or services. The 
export variable therefore takes a simple form as a dummy with a value of zero representing no exporting activity and 1 where the owner or manager has indicated that the firm exported at least some of their production in 2016.

\subsection{Measures of Innovation}

The focus in this study is on inbound open innovation in terms of the sourcing/purchasing of information to generate new innovations for the firm, rather than outbound open innovation where others may benefit from the information revealed (Dahlander \& Gann, 2010). As discussed in the preceding sections, innovations can take a wide range of forms (Huggins, Johnston, \& Thompson, 2012; Murphy, Huggins, \& Thompson, 2016). Many studies try to capture innovation through observable measures such as patents acquired (Percoco, 2013). However, this can often ignore a large amount of hidden innovation that may often be more important for the firms and localities involved (Halkett, 2008; NESTA, 2007). This hidden innovation may include smaller more incremental innovations, particularly those relating to services provided or processes used in production, as patenting such processes allows them to be copied and infringement is hard to identify or prove (Arundel \& Kabla, 1998). These may be more important to smaller more entrepreneurial firms who have smaller R\&D budgets (Kitching \& Blackburn, 1998). Smaller firms may also be less likely to patent even those innovations for which there is potential, as they lack the resources to defend any infringements. Instead they prefer to keep such advantages as 'industry secrets' or exploit them through 'speed to market' (Leiponen \& Byma, 2009).

Within the LSBS two items are included relating to whether the firm introduced any new or significantly improved goods or services in the last three years. A third measure also accounts for whether new or significantly improved processes for producing or supplying goods and 
services have been introduced in the same time period. These are combined to determine whether the firm can be classed as generating either product/service or process innovations in the period 2012 to 2015 .

In order to further examine the nature of this innovation the source of the new ideas is examined. If the products, services, or processes were generated with co-operation of others this might be considered a form of open innovation (Chesbrough, 2003). For those introducing an innovation of any type the LSBS includes an item enquiring as to whether this involved the cooperation of any of a list of potential partners: businesses within your enterprise group; suppliers of equipment, materials, services or software; clients or customers from the private sector; clients or customers from the public sector; competitors or other businesses in the same industry; consultants, commercial labs or private R\&D institutes; universities or higher education institutions; government or public research institutes. As the focus here is on whether the presence of foreign firms has an important role in generating innovations that are export orientated or not we concentrate on co-operation with: other businesses in the same sector, suppliers of equipment or materials, clients or customers, and competitors. This ignores the potential for cooperation with public sector partners and consultants, which may be an important avenue for future work. The innovation measure produced categorises firms into one of three groups, those with no innovations, those with innovations produced without cooperation with other firms, and those with innovations produced through cooperation with other firms.

It should be noted that unfortunately the form such cooperation takes is not recorded in the data. For example, whether the relationship is on a pecuniary or non-pecuniary basis (Dahlander \& Gann, 2010), and the extent relationships are formed in a strategic calculative 
fashion to boost innovation or more socially embedded (Huggins \& Thompson, 2017), is not available. As noted in sub-section 2.2 above, work has noted the reliance of SMEs on local network ties (Huggins, Johnston, \& Thompson, 2012), and the importance of face to face communication in transferring complex knowledge in the globalised dynamic economy (Dahlander and Gann, 2010; McCann, 2008). As outlined below it is expected that local foreign influence will influence the nature of these collaborations, but unfortunately the LSBS data does not directly distinguish between innovation generated with local and nonlocal collaboration.

\subsection{Measures of Foreign Influence}

Given the uneven distribution of FDI within both countries and regions (Yehoue, 2009), it is recognised that the benefits and costs to local SMEs may vary considerably from area to area (Hu, 2007). There are no official measures of FDI at the local level available in the UK (Billington, 1999), although one off cross sectional analysis have been produced for regions (Hill \& Munday, 1991). This means there is no default measure of FDI utilised in similar studies to this.

Instead a wide range of different measures have been used including, the number of projects (Dimitropoulou, McCann, \& Burke, 2013), and the proportion of employment in foreign firms (Thompson \& Zang, 2015, 2016, 2018). Here the focus is on the opportunity to cooperate with foreign firms in order to innovate. The focus therefore is not only the impact of foreign firms in the labour market, or necessarily flows of investment, but the availability of potential partners. Therefore, in order to understand the impact of foreign firms in the local area this is captured by the presence of foreign firms measured as a proportion of all firms. 
This data is based upon the 'Foreign Ownership of Businesses in the United Kingdom Analysis' (ONS, 2010). Figures from 2011 are used in preference to more recent figures as the innovation measure as discussed above considers innovations produced between 2012 and 2015, which may have required interactions before this period. The data is measured at the local enterprise partnership (LEP) level. In England there are 39 LEPs. These are intended to be based more around the distribution of economic activities rather than arbitrary administrative distinctions. However, recognising this LEPs do overlap in places. The LEP utilised for each firm is that which is designated as their primary LEP, which presumably will reflect where the owner or manager feels that the business has most affiliation and interactions.

\subsection{Multi-level Regression Analysis}

Whether firms are active exporters in 2016 is explored using regression analysis with controls for the firms' characteristics drawn from the data collected in 2015. This helps to reduce issues of reverse causality, although ideally in the future the LSBS with additional years of data will allow panel data approaches to be applied further helping isolate causal relationships.

As the dependent variable is whether firms export or not, it takes a discrete form and is better examined using approaches based on binary logistic regressions. The relationships of key interest are those relating to how firms' innovative activities and the presence of foreign businesses affect the decision to export. However, whilst the former is measured at the level of the firm, the presence of foreign firms is measured at the LEP level. This means that a multi-level regression approach will be more appropriate. Ignoring the different level of measurement of independent variables can have consequences for the efficiency of the 
regressions if separate terms are estimated for each LEP, and ignores the likelihood of clustering of more or less innovative types of firm within certain LEP (Rasbash, Steele, Browne, \& Goldstein, 2017). This clustering will generally lead to the under-estimating of standard errors, which can lead to relationships being incorrectly identified as having a significant impact.

For firm $i$ in LEP $j$ the variable of interest reflecting the choice to export (Exportij) will take the value 1 if the firm has exported at least some of its turnover in the form of goods or services and 0 otherwise. The regression therefore takes the following form:

$p_{i j}=\operatorname{Pr}\left(\right.$ Exports $_{i j}=1 \mid$ Innovation $_{i j}$, Foreign $\left._{j}\right)$

$\operatorname{Logit}\left(p_{i j}\right)=\beta_{0}+\beta_{1}$ Innovation $_{i j}+\beta_{2}$ Foreign $_{j}+\beta_{3}$ Innovation $_{i j} \cdot$ Foreign $_{j}+u_{0 j}$

$\operatorname{Var}\left(u_{0 j} \mid\right.$ Innovation $_{i j}$, Foreign $\left._{j}\right)=\sigma_{u_{0} \mid \text { Innovation,Foreign }}^{2}$

Where the probability of choosing to export $\left(p_{i j}\right)$ is regressed on the innovation activity of firm $i$ in LEP $j$ (Innovation $i j$ ). The contextual effect is captured by examining the presence of foreign firms as a proportion of all firms in LEP $j$ (Foreign $n_{j}$. In order to examine the evidence for foreign influence increasing exporting propensity via the mechanism of boosting productivity and new product development the term Innovation $_{i j}$-Foreign $n_{j}$ is included, where a significant coefficient $\beta_{3}$ will reflect an interaction between the firm level and the local area factors.

\subsection{Controls}

As studies have suggested that there is a fixed cost, which must be overcome before exporting (Chen et al., 2013; Helpman et al., 2004; Kneller \& Pisu, 2007), the availability of resources will be important (Majocchi, Bacchiocchi, \& Mayrhofer, 2005). These resources 
can come in a number of forms. As with all controls these are drawn from the responses of managers and owners in 2015.

Larger firms may have both greater financial and human capital, therefore the size of the business, as captured by the natural $\log$ of employment plus 1, is included (Serra, Pointon, \& Abdou, 2012). Experience and understanding along with market reputation will also be built up over time, so the natural $\log$ of the age of the business plus 1 is also included (Katsikeas, Deng, \& Wortzel, 1997).

The leadership of the business is perhaps the most important source of human capital (Ganotakis \& Love, 2012). In recognition of the fact that many businesses are not founded by single individuals, but by teams (Gartner, Shaver, Gatewood, \& Katz, 1994), we control for the number of directors. This will also be an important source of knowledge and information about prospective partners, markets and opportunities for more well developed businesses (Ucbasaran, Lockett, Wright, \& Westhead, 2003). To account for this the natural log of the number of directors and partners plus 1 is included.

Constraints may be imposed by managers on the drive to enter additional markets where there is less desire to grow (De Clercq, Sapienza, \& Crijns, 2005). To account for this we include a dummy for those indicating that they wish to increase their sales over the next three years. Current performance may also constrain businesses. Where firms have increased turnover in the last 12 months there may be more opportunity to enter new markets rather than concentrating on existing markets (Morgan \& Katsikeas, 1997). Similarly profitable firms will generate the cash required to make investments in the required relations and infrastructure that may be out of reach of other less successful firms (Morgan \& Katsikeas, 
1997). This might be particularly important as fixed capital investments are linked to exporting through the increases in productivity it generates (Seo, Lee, \& Kim, 2012), but the liabilities of newness combined with the risk of entering new export markets will put off many external sources of capital (Riding, Orser, Spence, \& Belanger, 2012). To capture the former, past performance relating to turnover is split into three categories, shrinking, remaining the same, and increasing with dummies reflecting the shrinking and increasing outcomes compared to the base of remaining the same. In terms of profitability a dummy is included to reflect those businesses currently turning a profit. Controls are also included for industry to reflect the different opportunities available to firms depending on the nature of their outputs.

\section{Results}

Table 1 shows the bivariate correlations of the variables used in the regression analysis. The non-parametric Spearman rank correlation coefficients are used as some variables are ordinal. Foreign influence in the market is positively correlated with the decision to export (Kneller \& Pisu, 2007; Golovko \& Valentini, 2011; Greenaway et al., 2004). Innovation in general, product innovation and process innovation are all positively correlated with the decision to export. The likelihood of exporting is positively associated with the size of business captured by the number of employees (Serra et al., 2012; Thompson \& Zang, 2016) and the age of business; the leadership of the business as measured by the number of directors, the current performance of the business in terms of growth and profits; and the future intension to grow sales.

Please Insert Table 1 Here 
Table 2 presents the multi-level regression results for all innovation when not distinguishing between product or process innovations. It confirms a positive relationship exists between foreign influence and export propensity, consistent with the findings of Kneller and Pisu (2007), Golovko and Valentini (2011), and Greenaway et al. (2004). Both in-house innovation and open innovation positively contribute to the likelihood of exporting, which is consistent with Hypothesis H1. The absolute value of the coefficient estimated for the effect of in-house innovation is bigger than that of open innovation. However, the difference is extremely small and insignificant $\left(\chi^{2}=0.142\right.$, p-value 0.706$)$, with the odds ratios indicating that both in-house (odds ratio $=1.97)$ and open innovation (odds ratio $=1.89)$ roughly double the likelihood of exporting, so Hypothesis H2 is not supported. The results are consistent with Golovko and Valentini's (2011) findings that engaging in either product innovation or process innovation positively and significantly affects the decision to export, although they don't distinguish between in-house and open innovation. In addition, the interaction term of in-house innovation and foreign influence is negative and insignificant. However, open innovation interacts negatively with foreign influence to offset some of the positive effect of innovation. This indicates that open innovation increases export propensity to a lesser degree in areas with higher levels of foreign influence, which is contrary to Hypothesis H3b.

Other significant influences found include the size of business measured as the number of employees which is consistent with the findings of Serra et al. (2012) in Portugal; Thompson and Zang (2016) in the UK. In addition, consistent with there being a learning process associated with access to new markets (Katsikeas et al., 1997), the age of business is found to be positively related to export propensity. Moreover, firms that intend to increase sales over the next three years are more likely to export (De Clercq et al., 2005). 
Please Insert Table 2 Here

Table 3 shows the results of product innovation. The product innovation results are similar to those in Table 2 for innovation as a whole. Both in-house product innovation and open product innovation are significant, supporting Hypothesis H1 and Esteve-Pérez and Rodríguez (2013)'s results. The coefficient on open product innovation is slightly bigger than that of in-house product innovation, but not significantly so $\left(\chi^{2}=0.084\right.$, p-value 0.772$)$. The odds-ratios indicate both roughly double the likelihood of exporting (in-house innovation = 1.94; open innovation $=2.00$ ), providing no support for Hypothesis H2. In addition, there is no evidence to support Hypotheses $3 \mathrm{a}$ and $3 \mathrm{~b}$ due to the insignificant interaction terms.

Please Insert Table 3 Here

Turning to process innovations, the results in Table 4 show that the probability of exporting is increased due to both in-house process innovation and open process innovation confirming the Hypothesis H1 and Esteve-Pérez and Rodríguez's (2013) results. The coefficient for inhouse innovation conducted in isolation is larger, contradictory to Hypothesis H2. This difference is better presented by the odds ratios where in-house process innovation increases the likelihood of exporting by approaching two thirds (odds ratio $=1.64$ ), while the impact of open innovation is only to raise the likelihood by a quarter (odds ratio $=1.28$ ), but is not significant $\left(\chi^{2}=2.357, \mathrm{p}\right.$-value 0.125$)$. Interestingly, the signs on the two interaction terms would infer that in-house process innovation increases export propensity to a greater degree in areas with higher levels of foreign influence and open process innovation increases export propensity to a lesser degree with higher levels of foreign influence. In the case of in-house process innovation the interaction term coefficient is insignificant. However, the negative 
interaction between open innovation and the presence of foreign firms is significant at the ten percent level.

Please Insert Table 4 Here

Table 5 presents the results when both product innovation and process innovation are allowed to enter independently. Both open product innovation and in-house product innovation are significant, the coefficient of open product innovation (odds ratio $=2.04$ ) is larger than for inhouse product innovation (odds ratio $=1.72)$, but not significantly so $\left(\chi^{2}=1.541\right.$, p-value $=$ 0.214). This means there is only statistical support for Hypotheses $\mathrm{H} 1$ not $\mathrm{H} 2$. The interaction term between in-house product innovation and foreign influence is negative and significant, which is consistent with Hypothesis H3a. This would be consistent with domestic firms that engage in in-house product innovation in the presence of foreign firms either, lose export drive and focus on serving the foreign affiliates instead, or simply are weakened by the competition effect. However, the interaction terms between open product innovation and foreign influence is not significant, proving no support for Hypothesis H3b.

Turning to process innovation, in-house process innovation alone significantly increases the probability of exporting (odds ratio $=1.51$ ). However, this increase in the likelihood of exporting is stronger in areas with more foreign influence, which is contradictory to Hypothesis H3a.This would be consistent with in-house process innovation boosting exports more in the presence of foreign firms due to positive knowledge spillovers (Acs et al., 2007; $\mathrm{Fu}, 2012)$. Open process innovation alone is not significant and understandably now significantly different from in-house process innovation $\left(\chi^{2}=4.78, \mathrm{p}\right.$-value 0.029$)$. The interaction term between open process innovation and foreign influence is negative and 
significant. This means there is no support for either Hypotheses $\mathrm{H} 1$ and H3b. Open process innovation has no effect on exports, it reduces the likelihood of exporting in areas with more foreign influence. This may mean rather than benefiting from knowledge spillovers, domestic firms focus on serving large foreign firms' local affiliates, to the detriment of exploiting export markets (Román et al., 2011; Thompson \& Zang, 2018).

Please Insert Table 5 Here

\section{Conclusions}

This study has utilised the LSBS data in the UK to examine whether multi-level regression analysis can find any evidence of export spillover activity from foreign firms' affiliates to domestic SMEs. In particular, the study has sought to examine whether open innovation provided one mechanism through which FDI might boost the export performance of domestic SMEs by increasing their productivity and product novelty.

Drawing on the existing literature, theory suggests that foreign influence in the local economy can have both a positive and negative impact on domestic SME export propensity. The empirical results also are not unanimous where more positive export spillovers might be found for more established domestic firms (Greenaway et al., 2004). More negative results might be more consistent with more entrepreneurial samples (Thompson \& Zang, 2016), where the primary selection effect might relate to the choice to start a business in the first place (Grossman, 1984). The data used here relates to more established SMEs, explaining the positive impact on export propensity found from a greater presence of foreign firms in the local economy. 
With regard to the mechanism of focus in this study, it was expected that innovation in general (Hypothesis H1) and open innovation in particular (Hypothesis H2) would have a positive effect on exporting activities. Whilst the study has found greater evidence for the former, the additional benefits of open innovation with regard to exporting appear relatively muted. In fact, process innovations display a stronger relationship when produced as in-house innovations. This goes against the studies that have suggested the importance of openinnovation in the modern economy where goods are parts in wider systems (Huggins \& Johnston, 2009; Lechner \& Dowling, 2003), but would be consistent with those studies highlighting the difficulties of SMEs protecting their intellectual property, particularly that relating to process innovations (Arundel \& Kabla, 1998; Leiponen \& Byma, 2009).

These important differences are apparent when considering the moderating influence of foreign firms, particularly when controlling for both types of innovation. Whereas the literature suggested that the negative effect of competing for customers and resources would hurt the in-house export relationship (De Backer \& Sleiwaegen, 2003; Girma et al., 2001) (Hypothesis $\mathrm{H} 3 \mathrm{a}$ ), the internationalisation potential from the outcomes of open innovation were expected to be greater where knowledge is gained from foreign affiliates either directly or indirectly (Lecerf, 2012) (Hypothesis H3b). These hypotheses turned out to be too simplistic and did not account for the important differences found for the different types of innovation, product or process. Whereas Hypothesis $\mathrm{H} 3 \mathrm{a}$ is supported for product innovations, the opposite result is found for process innovations as those innovating in-house appear to gain most with regard to export propensity when foreign influence is greater. As noted above, it appears that it is key to recognise that even today patenting and securing intellectual property is difficult for SMEs (Halkett, 2008; NESTA, 2007), and particularly so for process innovations (Arundel \& Kabla, 1998; Leiponen \& Byma, 2009). The results 
indicate that knowledge spillovers may boost productivity and aid innovation, but for process innovations, to protect any advantage gained more formal collaboration may not be wise to engage in. Although Hypothesis $\mathrm{H} 3 \mathrm{~b}$ that open innovation has more impact on exporting activities when foreign influence is greater is not supported for either type of innovation, unlike in-house product innovation there is no negative interaction with foreign presence for open product innovation. This is suggestive of knowledge benefits offsetting any competition effect. However, process innovations indicate the opposite.

From the results produced here it appears that domestic SMEs can be encouraged to increase their exporting activities where there is a greater presence of foreign firms. This may be particularly important in coming years due to the uncertainty created by Brexit, which may both reduce local demand in the UK (Office for Budget Responsibility, 2017) and require UK SMEs to seek out new overseas markets as access to traditional export markets is either made more difficult or at the least less certain. Given the danger of internationally orientated entrepreneurs choosing to locate outside the UK once it leaves the European Union, preservation and promotion of exporting activities becomes more important (Cumming \& Zahra, 2016). However, the results found here indicate that the relationship is much more complicated when considering the mechanism of foreign firms helping to generate innovative outcomes. For product innovations any export spillovers appear to come with a cost in terms of the competition effect reducing the exporting propensity of innovative firms. This can be overcome where domestic SMEs engage in open innovation to strengthen the gains from working in an environment where firms are operating near the technological frontier (Haskel, Pereira, \& Slaughter, 2007). However, with regard to process innovations, the opposite appears to be the case. The uneven power relationship and difficulty securing intellectual property in regard to processes (Christopherson \& Clark, 2007), mean that SMEs may gain 
through knowledge spillovers, but must complete innovation in-house to retain their advantages.

This means that managers of SMEs need to take care in their relationships with foreign affiliates with regard to innovation. Gains can be achieved through the use of knowledge spillovers, but whilst a more active engagement is needed for product innovation to offset any competition effect, the opposite is the case for process innovation. For policymakers the results are just as important. In the face of BREXIT and other negative shocks, FDI can look attractive. It appears that domestic firms may benefit in terms of export spillovers, but policymakers must be aware which firms are gaining. From the results here more innovative firms do not appear to always be beneficiaries and in the case of product innovators may actually lose out unless they adopt an open innovation approach. This may require training provision on how to handle such relationships.

As with most studies there is a need to determine if the relationships found here are particular to the UK, or can be found in other countries. Longitudinal data, particularly that which examines with which firms particular open innovation relationships are formed, would help to further check the mechanisms suggested here. However, a key result found by this study is that when considering the impact of FDI on domestic SMEs' export propensity their innovative nature must be taken into account in terms of: whether they innovate, what type of innovation, and how is this innovation conducted. For future work, where open innovation is used, further clarity on the form these relationships take in terms of their formalisation and organisation may also be important with regard to the type of innovation generated and benefits accrued at the firm, industry and local/regional levels (Bogers et al., 2019; Dahlander \& Gann, 2010; Huggins and Thompson, 2017; McCann, 2008). 


\section{References}

Acs, Z. J., Audretsch, D. B., \& Lehmann, E. E. (2013). The knowledge spillover theory of entrepreneurship. Small Business Economics 41, 757-774. doi: 10.1007/s1 1 187-013-9505-9 Acs, Z. J., O’Gorman, C., Szerb, L., \& Terjesen, S. (2007). Could the Irish miracle be repeated in Hungary? Small Business Economics 28, 123-142. doi: 10.1007/s1 1187-006$9027-9$

Anderson, A., Dodd, S. D., \& Jack, S. (2010). Network practices and entrepreneurial growth. Scandinavian Journal of Management 26, 121-133. doi: 10.1016/j.scaman.2010.01.005

Arundel, A., \& Kabla, I. (1998). What percentage of innovations are patented? Empirical estimates for European firms. Research Policy 27, 127-141. doi: 10.1016/S00487333(98)00033-X

Audretsch, D. B., \& Lehmann, E. E. (2005). Does the knowledge spillover theory of entrepreneurship hold for regions. Research Policy 34, 1191-1202. doi: 10.1016/j.respol.2005.03.012

Barbosa, N., \& Eiriz, V. (2009). The role of inward foreign direct investment on entrepreneurship. International Entrepreneurship and Management Journal 5, 319-339. doi: $10.1007 / \mathrm{s} 11365-007-0050-3$

Bathelt, H., Malmberg, A., \& Maskell, P. (2004). Clusters and knowledge: Local buzz, global pipelines and the process of knowledge creation. Progress in Human Geography 28, 31-56. doi: 10.1191/0309132504ph469oa

Bernard, A., \& Jensen, J. B. (2004). Why some firms export. Review of Economics and Statistics 86, 628-639. doi: 10.1162/003465304323031111

Billington, N. (1999). The location of foreign direct investment: An empirical analysis. Applied Economics 31, 65-76. doi: 10.1080/000368499324561 
Bogers, M., Zobel, A.-K., Afuah, A., Almirall, E., Brunswicker, S., Dahlander, L., ... Ter Wal, A. L. J. (2019). The open innovation research landscape: Established perspectives and emerging themes across different levels of analysis. Industry and Innovation 24, 8-40. doi: $10.1080 / 13662716.2016 .1240068$

Chen, C., Sheng, Y., \& Findlay, C. (2013). Export spillovers of FDI on China's domestic firms. Review of International Economics 21, 841-856. doi: 10.1111/roie.12074

Chesbrough, H. (2003). Open innovation: The new imperative for creating and profiting from technology. Boston, MA: Harvard Business School Press.

Chesbrough, H., \& Crowther, A. K. (2006). Beyond high tech: Early adopters of open innovation in other industries. $R \& D$ Management 36, 229-236. doi: 10.1111/j.14679310.2006.00428.x

Chesbrough, H., Vanhaverbeke, W., \& West, J. (eds.) (2006). Open innovation: Researching a new paradigm. Oxford: Oxford University Press.

Christopherson, S., \& Clark, J. (2007). Power in firm networks: What it means for regional innovation systems. Regional Studies 41, 1223-1236. doi: 10.1080/00343400701543330

Cumming, D. J., \& Zahra, S. A. (2016). International business and entrepreneurship implications of Brexit. British Journal of Management 27, 687-692. doi: 10.1111/14678551.12192

Dahlander, L., \& Gann, D. M. (2010). How open is innovation? Research Policy 39, 699709. doi: 10.1016/j.respol.2010.01.013

De Backer, K., \& Sleuwaegen, L. (2003). Does foreign direct investment crowd out domestic entrepreneurship. Review of Industrial Organization 22, 67-84. doi: 10.1023/A:1022180317898 
De Clercq, D., Sapienza, H. J., \& Crijns, H. (2005). The internationalization of small and medium-sized firms. Small Business Economics 24, 409-419. doi: 10.1007/s11187-005-5333$\mathrm{X}$

Department for Business Innovation and Skills (2016). Longitudinal small business survey year 1 (2015): Technical appendix. BIS Research Paper Number 291, Department for Business Innovation and Skills, London, May 2016.

Desrochers, P. (2001). Geographical proximity and the transmission of tacit knowledge. Review of Austrian Economics 14, 25-46. doi: 10.1023/A:1007803520748

Dimitropoulou, D., McCann, P., \& Burke, S. P. (2013). The determinants of the location of foreign direct investment in UK regions. Applied Economics 45, 3853-3862. doi: $10.1080 / 00036846.2011 .558482$

Effekhari, N., \& Bogers, M. (2015). Open for entrepreneurship: How open innovation can foster new venture creation. Creativity and Innovation Management 24, 574-584. doi: 10.1111/caim.12136

Esteve-Pérez, S., \& Rodríguez, D. (2013). The dynamics of exports and R\&D in SMEs. Small Business Economics 41, 219-240. doi: 10.1007/s11187-012-9421-4

Freel, M. S., \& Robson, P. J. A. (2004). Small firm innovation, growth and performance: Evidence from Scotland and Northern England. International Small Business Journal 22, 561-575. doi: $10.1177 / 0266242604047410$

Fritsch, M., \& Schwirten, C. (1999). Enterprise-university cooperation and the role of public research institutions in regional innovation systems. Industry and Innovation 6, 69-83. doi: $10.1080 / 13662719900000005$

$\mathrm{Fu}, \mathrm{X}$. (2012). Foreign direct investment and managerial knowledge spillovers through the diffusion of management practices. Journal of Management Studies 49, 970-999. doi: 10.1111/j.1467-6486.2011.01036.x 
Ganotakis, P., \& Love, J. H. (2012). Export propensity, export intensity and firm performance: The role of the entrepreneurial founding team. Journal of International Business Studies 43, 693-718. doi: 10.1057/jibs.2012.16

Gartner, W. B., Shaver, K. G., Gatewood, E., \& Katz, J. A. (1994). Finding the entrepreneur in entrepreneurship. Entrepreneurship Theory and Practice 18, 5-10. doi: $10.1177 / 104225879401800301$

Gassmann, O., \& Enkel, E. (2004). Towards a theory of open innovation: Three core process archetypes. Proceedings of the R\&D Management Conference, Lisbon, Portugal, July 6-9, Blackwell, Oxford.

Girma, S., Greenaway, D., \& Wakelin, K. (2001). Who benefits from foreign direct investment in the UK? Scottish Journal of Political Economy 48, 119-133. doi: $10.1111 / 1467-9485.00189$

Goerzen, A. (2005). Managing alliance networks: Emerging practices of multinational corporations. Academy of Management Executive 19, 94-107. doi: 10.5465/ame.2005.16965102

Golovko, E., \& Valentini, G. (2011). Exploring the complementarity between innovation and export for SMEs' growth. Journal of International Business Studies 42, 362-380. doi: $10.1057 /$ jibs.2011.2

Grant, R., \& Baden-Fuller, C. (2004). A knowledge accessing theory of strategic alliances. Journal of Management Studies 41, 61-84. doi: 10.1111/j.1467-6486.2004.00421.x

Greenaway, D., Sousa, N., \& Wakelin, K. (2004). Do domestic firms learn to export from multinationals. European Journal of Political Economy 20, 1027-1043. doi: 10.1016/j.ejpoleco.2003.12.006

Grossman, G. M. (1984). International trade, foreign investment, and the formation of the entrepreneurial class. American Economic Review 74, 605-614. 
Halkett, R. (2008). New innovation, new policy, new metrics? paper presented at the International Workshop on New Directions for Innovation Measurement and its Use for Strategy Policy, 13 May, available at: http://stip.gatech.edu/wpcontent/uploads/2010/05/Uncovering-Innovation-ppt-Richard-Halkett.pdf.

Hall, B. H., Lotti, F., \& Mairesse, J. (2009). Innovation and productivity in SMEs: Empirical evidence for Italy. Small Business Economics 33, 13-33. doi: 10.1007/s11187-009-9184-8

Haskel, J. E., Pereira, S. C., \& Slaughter, M. J. (2007). Does inward foreign direct investment boost the productivity of domestic firms? Review of Economics and Statistics 89, 482-496. doi: $10.1162 /$ rest.89.3.482

Helpman, E., Melitz, M., \& Yeaple, S. (2004). Export versus FDI with heterogeneous firms. American Economic Review 94, 300-316. doi: 10.1257/000282804322970814

Henkel, J. (2006). Selective revealing in open innovation processes: The case of embedded Linux. Research Policy 35, 953-969. doi: 10.1016/j.respol.2006.04.010

Hill, S., \& Munday, M. (1991). The UK regional distribution of foreign direct investment: Analysis and determinants. Regional Studies 26, 535-544. doi: $10.1080 / 00343409212331347181$

Hu, A. G. (2007). Technology parks and regional economic growth in China. Research Policy 36, 76-87. doi: 10.1016/j.respol.2006.08.003

Hu, Y., McNamara, P., \& McLoughlin, D. (2015). Outbound open innovation in biopharmaceutical out-licensing. Technovation 35, 46-58. doi: 10.1016/j.technovation.2014.07.004

Huggins, R., \& Johnston, A. (2009). Knowledge networks in an uncompetitive region: SME innovation and growth. Growth and Change 40, 227-259. doi: 10.1111/j.14682257.2009.00474.x 
Huggins, R., Johnston, A., \& Thompson, P. (2012). Network capital, social capital and knowledge flow: How the nature of inter-organizational networks impacts on innovation. Industry and Innovation 19, 203-232. doi: 10.1080/13662716.2012.669615

Huggins, R., \& Thompson, P. (2017). Entrepreneurial networks and open innovation: The role of strategic and embedded ties. Industry and Innovation 24, 403-435. doi: $10.1080 / 13662716.2016 .1255598$

Jack, S., Moult, S., Anderson, A. R., \& Dodd, S. (2010). An entrepreneurial network evolving: Patterns of change. International Small Business Journal 28, 315-337. doi: $10.1177 / 0266242610363525$

Katila, R., \& Ahuja, G. (2002). Something old, something new: A longitudinal study of search behaviour and new product introduction. Academy of Management Journal 45, 1183 1194. doi: $10.5465 / 3069433$

Katsikeas, C., Deng, S., \& Wortzel, L. (1997). Perceived export success factors of small and medium-sized Canadian firms. Journal of International Marketing 5, 53-72. doi: $10.1177 / 1069031 X 9700500405$

Ke, S. (2010). Determinants of economic growth and spread-backwash effects in Western and Eastern China. Asian Economics Journal 24, 179-202. doi: 10.1111/j.14678381.2010.02032.x

Kitching, J., \& Blackburn, R. (1998). Intellectual property management in the small and medium enterprise (SME). Journal of Small Business and Enterprise Development 5, 327335. doi: 10.1108/EUM0000000006797

Kneller, R., \& Pisu, M. (2007). Industrial linkages and export spillovers from FDI. World Economy 30, 105-134. doi: 10.1111/j.1467-9701.2007.00874.x 
Laursen, K., \& Salter, A. J. (2006). Open for innovation: The role of openness in explaining innovation performance among UK manufacturing firms. Strategic Management Journal 27, 131-150. doi: 10.1002/smj.507

Lawton Smith, H., Romeo, S., \& Virahsawmy, M. (2012). Business and professional networks: Scope and outcomes in Oxfordshire. Environment and Planning A 44, 1801-1818. doi: $10.1068 / \mathrm{a} 44461$

Lecerf, M.-A. (2012). Internationalization and innovation: The effects of a strategy mix on the economic performance of French SMEs. International Business Research 5, 2-13. doi: 10.5539/ibr.v5n6p2

Lechner, C., \& Dowling, M. (2003). Firm networks: External relationships as sources for the growth and competitiveness of entrepreneurial firms. Entrepreneurship and Regional Development 15, 1-26. doi: 10.1080/08985620210159220

Lee, S., Park, G., Yoon, B., \& Park, J. (2010). Open innovation in SMEs - an intermediated network model. Research Policy 39, 290-300. doi: 10.1016/j.respol.2009.12.009

Leiponen, A., \& Byma, J. (2009). If you cannot block, you better run: Small firms, cooperative innovation, and appropriation strategies. Research Policy 38, 1478-1488. doi: 10.1016/j.respol.2009.06.003

Liu, Z. (2008). Foreign direct investment and technology spillovers: Theory and evidence. Journal of Development Economics 85, 176-193. doi: 10.1016/j.jdeveco.2006.07.001

Love, J. H., \& Roper, S. (2015). SME innovation, exporting and growth: A review of existing evidence. International Small Business Journal 33, 28-48. doi: 10.1177/0266242614550190

Majocchi, A., Bacchiocchi, E., \& Mayrhofer, U. (2005). Firm size, business experience and export intensity in SMEs: A longitudinal approach. International Business Review 14, 719738. doi: 10.1016/j.ibusrev.2005.07.004 
Markusen, J. R., \& Venables, A. J. (1999). Foreign direct investment as a catalyst for industrial development. European Economic Review 43, 335-356. doi: 10.1016/S00142921(98)00048-8

Marques, C. S., \& Ferreira, J. (2009). SME innovative capacity, competitive advantage and performance in a 'traditional' industrial region of Portugal. Journal of Technology and Innovation 4, 53-68. doi: 10.4067/S0718-27242009000400005

Martins, P. (2011). Paying more to hire the best? Foreign firms, wages and worker mobility. Economic Inquiry 49, 349-363. doi: 10.1111/j.1465-7295.2010.00301.x

Maskell, P., \& Lorenzen, M. (2004). The cluster as market organization. Urban Studies 41, 991-1009. doi: 10.1080/00420980410001675878

Maurer, I., \& Ebers, M. (2006). Dynamics of social capital and their performance implications: Lessons from biotechnology start-ups. Administrative Science Quarterly 51, 262-292. doi: 10.2189/asqu.51.2.262

McCann, P. (2008). Globalization and economic geography: The world is curved, not flat. Cambridge Journal of Regions, Economy and Society 1, 351-370. doi: 10.1093/cjres/rsn002

Morgan, R. E., \& Katsikeas, C. S. (1997). Obstacles to export initiation and expansion. Omega, International Journal of Management Science 25, 677-690. doi: 10.1016/S03050483(97)00035-2

Murphy, L., Huggins, R., \& Thompson, P. (2016). Social capital and innovation: A comparative analysis of regional policies. Environment and Planning C 34, 1025-1057. doi: $10.1177 / 0263774 X 15597448$

NESTA (2007). Hidden innovation: How innovation happens in six low innovation sectors. NESTA Research Report, London.

Nonaka, I. (1991). The knowledge-creating company. Harvard Business Review 69, 96-104. 
ONS (2010). Foreign ownership of businesses in the United Kingdom. Office for National Statistics, London.

Office for Budget Responsibility (2017). Economic and fiscal outlook November 2017. APS Group, Cheadle Heath.

Percoco, M. (2013). Strategies of regional development in European regions: Are they efficient? Cambridge Journal of Regions, Economy and Society 6, 303-318. doi: $10.1093 /$ cjres/rst011

Rallet, A., \& Torre, A. (1999). Is geographical proximity necessary in the innovation networks in the era of global economy? GeoJournal 49, 373-380. doi: 10.1023/A:1007140329027

Rasbash, J., Steele, F., Browne, W. J., \& Goldstein, H. (2017). A User's Guide to MLwinN: Version 3.01. Bristol: University of Bristol.

Riding, A., Orser, B. J., Spence, M., \& Belanger, B. (2012). Financing new venture exporters. Small Business Economics 38, 147-163. doi: 10.1007/s11187-009-9259-6

Román, C., Congregado, E., \& Millán, J. M. (2011). Dependent self-employment as a way to evade employment protection legislation. Small Business Economics 37, 363-392. doi: $10.1007 / \mathrm{s} 11187-009-9241-3$

Sammarra, A., \& Biggiero, L. (2008). Heterogeneity and specificity of inter-firm knowledge flows in innovation networks. Journal of Management Studies 45, 800-829. doi: $10.1111 / \mathrm{j} .1467-6486.2008 .00770 . \mathrm{x}$

Scuotto, V., Santoro, G., Bresciani, S., \& Del Giudice, M. (2017). Shifting intra- and interorganizational innovation processes towards digital business: An empirical analysis of SMEs. Creativity and Innovation Management 26, 247-255. doi: 10.1111/caim.12221 
Seo, H. J., Lee, Y. S., \& Kim, H. (2012). The determinants of export market performance in Organisation for Economic Co-operation and Development service industries. Service Industries Journal 32, 1343-1354. doi: 10.1080/02642069.2010.550140

Serra, F., Pointon, J., \& Abdou, H. (2012). Factors influencing the propensity to export: A study of UK and Portuguese textile firms. International Business Review 21, 210-224. doi: 10.1016/j.ibusrev.2011.02.006

Thompson, P., \& Zang, W. (2015). Foreign direct investment and the SME sector. International Journal of Entrepreneurial Behaviour and Research 21, 50-75. doi: 10.1108/IJEBR-12-2013-0218

Thompson, P., \& Zang, W. (2016). Foreign business ownership and domestic entrepreneurial exports. Journal of Small Business and Enterprise Development 23, 873-895. doi: 10.1108/JSBED-10-2015-0138

Thompson, P., \& Zang, W. (2018). The foreign business and domestic enterprise relationship: Its implications for local entrepreneurial resilience. Local Economy 33, 10-39. doi: $10.1177 / 0269094218756817$

Ucbasaran, D., Lockett, A., Wright, M., \& Westhead, P. (2003). Entrepreneurial founder teams: Factors associated with member entry and exit. Entrepreneurship Theory and Practice 28, 107-128. doi: 10.1046/j.1540-6520.2003.00034.x

Vahter, P., Love, J. H., \& Roper, S. (2014). Openness and innovation performance: Are small firms different? Industry and Innovation 21, 553-573. doi: 10.1080/13662716.2015.1012825

van de Vrande, V., de Jong, J. P. J., Vanhaverbeke, W., \& de Rochemont, M. (2009) Open innovation in SMEs: Trends, motives and management challenges. Technovation 29, 423437. doi: 10.1016/j.technovation.2008.10.001

Wagner, J. (2007). Exports and productivity: A survey of the evidence from firm-level data. World Economy 30, 60-82. doi: 10.1111/j.1467-9701.2007.00872.x 
Wu, C.-H., Kao, S.-C., \& Shih, L.-H. (2010). Assessing the suitability of process and information technology in supporting tacit knowledge transfer. Behaviour and Information Technology 29, 513-525. doi: 10.1080/01449290903490666

Yehoue, E. B. (2009). Clusters as a driving engine for FDI. Economic Modelling 26, 934945. doi: 10.1016/j.econmod.2009.03.006

Zucchella, A., \& Hagen, B. (2012). The international growth of e-commerce ventures. In S. Harris, O. Kuivalainen, \& V. Stoyanova (Eds.), International Business: New Challenges, New Forms, New Perspectives (pp. 137-153). Basingstoke: Palgrave-Macmillan. 
Table 1 Spearman rank correlation coefficients of exporting propensity, foreign influence, innovation and other independent variables

\begin{tabular}{|c|c|c|c|c|c|c|c|c|c|c|}
\hline & $\begin{array}{c}1 . \\
\text { Exports }\end{array}$ & 2 & 3 & 4 & 5 & 6 & 7 & 8 & 9 & 10 \\
\hline 2. Foreign firms & $\begin{array}{c}0.098 \\
(0.000)\end{array}$ & & & & & & & & & \\
\hline 3. Employees & $\begin{array}{c}0.095 \\
(0.000)\end{array}$ & $\begin{array}{c}0.003 \\
(0.814)\end{array}$ & & & & & & & & \\
\hline 4. Directors & $\begin{array}{c}0.123 \\
(0.000)\end{array}$ & $\begin{array}{c}0.007 \\
(0.606)\end{array}$ & $\begin{array}{c}0.295 \\
(0.000)\end{array}$ & & & & & & & \\
\hline 5. Age & $\begin{array}{c}0.028 \\
(0.041)\end{array}$ & $\begin{array}{l}-0.041 \\
(0.003)\end{array}$ & $\begin{array}{c}0.226 \\
(0.000)\end{array}$ & $\begin{array}{c}0.089 \\
(0.000)\end{array}$ & & & & & & \\
\hline 6. Growth ${ }^{\mathrm{a}}$ & $\begin{array}{c}0.065 \\
(0.000)\end{array}$ & $\begin{array}{c}0.038 \\
(0.006)\end{array}$ & $\begin{array}{c}0.182 \\
(0.000)\end{array}$ & $\begin{array}{c}0.072 \\
(0.000)\end{array}$ & $\begin{array}{l}-0.073 \\
(0.000)\end{array}$ & & & & & \\
\hline 7. Profitable ${ }^{b}$ & $\begin{array}{c}0.034 \\
(0.015)\end{array}$ & $\begin{array}{l}-0.032 \\
(0.020)\end{array}$ & $\begin{array}{c}0.047 \\
(0.001)\end{array}$ & $\begin{array}{c}0.082 \\
(0.000)\end{array}$ & $\begin{array}{l}-0.003 \\
(0.807)\end{array}$ & $\begin{array}{c}0.185 \\
(0.000)\end{array}$ & & & & \\
\hline 8. Intend to grow ${ }^{c}$ & $\begin{array}{c}0.160 \\
(0.000)\end{array}$ & $\begin{array}{c}0.066 \\
(0.000)\end{array}$ & $\begin{array}{c}0.273 \\
(0.000)\end{array}$ & $\begin{array}{c}0.138 \\
(0.000)\end{array}$ & $\begin{array}{l}-0.051 \\
(0.000)\end{array}$ & $\begin{array}{c}0.206 \\
(0.000)\end{array}$ & $\begin{array}{c}0.001 \\
(0.950)\end{array}$ & & & \\
\hline 9. All innovation ${ }^{\mathrm{d}}$ & $\begin{array}{c}0.153 \\
(0.000)\end{array}$ & $\begin{array}{c}0.027 \\
(0.052)\end{array}$ & $\begin{array}{c}0.105 \\
(0.000)\end{array}$ & $\begin{array}{c}0.074 \\
(0.000)\end{array}$ & $\begin{array}{l}-0.022 \\
(0.117)\end{array}$ & $\begin{array}{c}0.121 \\
(0.000)\end{array}$ & $\begin{array}{c}0.016 \\
(0.250)\end{array}$ & $\begin{array}{c}0.219 \\
(0.000)\end{array}$ & & \\
\hline $\begin{array}{l}\text { 10. Product } \\
\text { innovation }\end{array}$ & $\begin{array}{c}0.156 \\
(0.000)\end{array}$ & $\begin{array}{c}0.023 \\
(0.104)\end{array}$ & $\begin{array}{c}0.080 \\
(0.000)\end{array}$ & $\begin{array}{c}0.053 \\
(0.000)\end{array}$ & $\begin{array}{l}-0.036 \\
(0.011)\end{array}$ & $\begin{array}{c}0.116 \\
(0.000)\end{array}$ & $\begin{array}{l}-0.003 \\
(0.830)\end{array}$ & $\begin{array}{c}0.193 \\
(0.000)\end{array}$ & $\begin{array}{c}0.856 \\
(0.000)\end{array}$ & \\
\hline $\begin{array}{l}\text { 11. Process } \\
\text { innovation }\end{array}$ & $\begin{array}{c}0.111 \\
(0.000)\end{array}$ & $\begin{array}{c}0.033 \\
(0.018)\end{array}$ & $\begin{array}{c}0.127 \\
(0.000)\end{array}$ & $\begin{array}{c}0.079 \\
(0.000)\end{array}$ & $\begin{array}{l}-0.013 \\
(0.337)\end{array}$ & $\begin{array}{c}0.123 \\
(0.000)\end{array}$ & $\begin{array}{c}0.031 \\
(0.028)\end{array}$ & $\begin{array}{c}0.193 \\
(0.000)\end{array}$ & $\begin{array}{c}0.612 \\
(0.000)\end{array}$ & $\begin{array}{c}0.375 \\
(0.000)\end{array}$ \\
\hline
\end{tabular}

Notes: p-values in parentheses; (a) higher values represent positive growth; (b) higher values represent the presence of profits; (c) higher values represent an intention to grow sales; (d) higher values represent open innovation; (e) higher values represent open product innovation; (f) higher values represent open process innovation. 
Table 2 All innovations: product or process innovations

\begin{tabular}{|c|c|c|}
\hline & Model 1 & Model 2 \\
\hline Foreign firms & $\begin{array}{c}\mathbf{0 . 4 5 6} * * * \\
(0.063)\end{array}$ & $\begin{array}{c}\mathbf{0 . 6 1 7} * * * \\
(0.101)\end{array}$ \\
\hline All in-house innovation & $\begin{array}{c}\mathbf{0 . 6 7 8} * * * \\
(0.115)\end{array}$ & $\begin{array}{c}\mathbf{0 . 6 9 5} * * * \\
(0.115)\end{array}$ \\
\hline All open innovation & $\begin{array}{c}\mathbf{0 . 6 3 7} * * * \\
(0.080)\end{array}$ & $\begin{array}{c}\mathbf{0 . 6 6 0} * * * \\
(0.081)\end{array}$ \\
\hline All in-house innovation $*$ Foreign firms & & $\begin{array}{c}-0.229 \\
(0.196)\end{array}$ \\
\hline All open innovation * Foreign firms & & $\begin{array}{c}\mathbf{- 0 . 2 5 9} * * \\
(0.131)\end{array}$ \\
\hline Employees & $\begin{array}{c}\mathbf{0 . 0 7 2} * * * \\
(0.025)\end{array}$ & $\begin{array}{c}\mathbf{0 . 0 7 3} * * * \\
(0.025)\end{array}$ \\
\hline Directors & $\begin{array}{c}0.102 \\
(0.062)\end{array}$ & $\begin{array}{c}0.102 \\
(0.062)\end{array}$ \\
\hline Age & $\begin{array}{c}\mathbf{0 . 2 1 3} * * * \\
(0.066)\end{array}$ & $\begin{array}{c}\mathbf{0 . 2 0 9} * * * \\
(0.066)\end{array}$ \\
\hline Negative growth & $\begin{array}{c}0.110 \\
(0.108)\end{array}$ & $\begin{array}{c}0.111 \\
(0.108)\end{array}$ \\
\hline Positive growth & $\begin{array}{c}0.103 \\
(0.081)\end{array}$ & $\begin{array}{c}0.105 \\
(0.081)\end{array}$ \\
\hline Profitable & $\begin{array}{c}0.030 \\
(0.107)\end{array}$ & $\begin{array}{c}0.037 \\
(0.107)\end{array}$ \\
\hline Intend to growth & $\begin{array}{c}\mathbf{0 . 6 7 0} * * * \\
(0.100)\end{array}$ & $\begin{array}{c}\mathbf{0 . 6 7 0} * * * \\
(0.100)\end{array}$ \\
\hline$N$ & 5142 & 5142 \\
\hline
\end{tabular}

Notes: Standard errors are in parentheses. Bold values are significant at $10 \%$ or better. ***, $* *$ and $*$ are significance level at $1 \%, 5 \%$ and $10 \%$ respectively. 
Table 3 Product innovations

\begin{tabular}{lcc}
\hline & Model 1 & Model 2 \\
\hline Foreign firms & $\mathbf{0 . 4 6 4 * * *}$ & $\mathbf{0 . 5 2 6} * * *$ \\
& $(0.063)$ & $(0.092)$ \\
In-house product innovation & $\mathbf{0 . 6 6 1} * * *$ & $\mathbf{0 . 6 6 7} * * *$ \\
Open product innovation & $(0.117)$ & $(0.117)$ \\
& $\mathbf{0 . 6 9 5 * * *}$ & $\mathbf{0 . 7 0 2} * * *$ \\
In-house product innovation * Foreign firms & $(0.078)$ & $(0.078)$ \\
& & -0.202 \\
Open product innovation * Foreign firms & & $(0.202)$ \\
& & -0.089 \\
Employees & & $(0.129)$ \\
Directors & $\mathbf{0 . 0 7 6 * * *}$ & $\mathbf{0 . 0 7 6} * * *$ \\
& $(0.025)$ & $(0.025)$ \\
Age & 0.102 & 0.101 \\
& $(0.062)$ & $(0.062)$ \\
Negative growth & $\mathbf{0 . 2 2 0} * * *$ & $\mathbf{0 . 2 1 9} * * *$ \\
Positive growth & $(0.066)$ & $(0.066)$ \\
Profitable & 0.124 & 0.125 \\
Intend to growth & $(0.108)$ & $(0.108)$ \\
$N$ & 0.107 & 0.108 \\
& $(0.081)$ & $(0.081)$ \\
& 0.050 & 0.054 \\
& $(0.108)$ & $(0.108)$ \\
& $\mathbf{0 . 6 7 2 * * *}$ & $\mathbf{0 . 6 7 2} * * *$ \\
& $(0.099)$ & $(0.100)$ \\
& 5142 & 5142 \\
\hline
\end{tabular}

Notes: Standard errors are in parentheses. Bold values are significant at $10 \%$ or better. ***, $* *$ and $*$ are significance level at $1 \%, 5 \%$ and $10 \%$ respectively. 
Table 4 Process innovations

\begin{tabular}{|c|c|c|}
\hline & Model 1 & Model 2 \\
\hline Foreign firms & $\begin{array}{c}\mathbf{0 . 4 3 6} * * * \\
(0.062)\end{array}$ & $\begin{array}{c}\mathbf{0 . 4 9 1} * * * \\
(0.076)\end{array}$ \\
\hline In-house process innovation & $\begin{array}{c}\mathbf{0 . 4 9 5} * * * \\
(0.157)\end{array}$ & $\begin{array}{c}\mathbf{0 . 4 6 7} * * * \\
(0.161)\end{array}$ \\
\hline Open process innovation & $\begin{array}{c}\mathbf{0 . 2 4 3} * * * \\
(0.080)\end{array}$ & $\begin{array}{c}\mathbf{0 . 2 6 0} * * * \\
(0.080)\end{array}$ \\
\hline In-house process innovation $*$ Foreign firms & & $\begin{array}{c}0.341 \\
(0.272)\end{array}$ \\
\hline Open process innovation $*$ Foreign firms & & $\begin{array}{c}-\mathbf{- 0 . 2 5 2} * \\
(0.134)\end{array}$ \\
\hline Employees & $\begin{array}{c}\mathbf{0 . 0 7 1} * * * \\
(0.025)\end{array}$ & $\begin{array}{c}\mathbf{0 . 0 7 3} * * * \\
(0.025)\end{array}$ \\
\hline Directors & $\begin{array}{c}0.105 \\
(0.061)\end{array}$ & $\begin{array}{c}0.109 \\
(0.061)\end{array}$ \\
\hline Age & $\begin{array}{c}\mathbf{0 . 2 0 5} * * * \\
(0.065)\end{array}$ & $\begin{array}{c}\mathbf{0 . 2 0 3} * * * \\
(0.065)\end{array}$ \\
\hline Negative growth & $\begin{array}{c}0.105 \\
(0.108)\end{array}$ & $\begin{array}{c}0.106 \\
(0.108)\end{array}$ \\
\hline Positive growth & $\begin{array}{c}0.136 \\
(0.080)\end{array}$ & $\begin{array}{c}0.135 \\
(0.080)\end{array}$ \\
\hline Profitable & $\begin{array}{c}0.022 \\
(0.107)\end{array}$ & $\begin{array}{c}0.017 \\
(0.107)\end{array}$ \\
\hline Intend to growth & $\begin{array}{c}\mathbf{0 . 7 5 7} * * * \\
(0.099)\end{array}$ & $\begin{array}{c}\mathbf{0 . 7 5 2} * * * \\
(0.099)\end{array}$ \\
\hline$N$ & 5142 & 5142 \\
\hline
\end{tabular}

Notes: Standard errors are in parentheses. Bold values are significant at $10 \%$ or better. ***, $* *$ and $*$ are significance level at $1 \%, 5 \%$ and $10 \%$ respectively. 
Table 5 Product and process innovations

\begin{tabular}{|c|c|c|}
\hline & Model 1 & Model 2 \\
\hline Foreign firms & $\begin{array}{c}\mathbf{0 . 4 6 2} * * * \\
(0.063)\end{array}$ & $\begin{array}{c}\mathbf{0 . 5 6 1} * * * \\
(0.095)\end{array}$ \\
\hline In-house product innovation & $\begin{array}{c}\mathbf{0 . 5 4 3} * * * \\
(0.129)\end{array}$ & $\begin{array}{c}\mathbf{0 . 5 3 3} * * * \\
(0.130)\end{array}$ \\
\hline Open product innovation & $\begin{array}{c}\mathbf{0 . 7 1 3} * * * \\
(0.084)\end{array}$ & $\begin{array}{c}\mathbf{0 . 7 1 0} * * * * \\
(0.085)\end{array}$ \\
\hline In-house process innovation & $\begin{array}{c}\mathbf{0 . 4 1 5} * * \\
(0.175)\end{array}$ & $\begin{array}{c}\mathbf{0 . 4 0 5} * * \\
(0.179)\end{array}$ \\
\hline Open process innovation & $\begin{array}{l}-0.009 \\
(0.089)\end{array}$ & $\begin{array}{c}0.016 \\
(0.090)\end{array}$ \\
\hline In-house product innovation $*$ Foreign firms & & $\begin{array}{c}-\mathbf{- 0 . 5 1 5} * * \\
(0.234)\end{array}$ \\
\hline Open product innovation $*$ Foreign firms & & $\begin{array}{c}0.056 \\
(0.141)\end{array}$ \\
\hline In-house process innovation $*$ Foreign firms & & $\begin{array}{c}\mathbf{0 . 6 3 8}^{* *} \\
(0.311)\end{array}$ \\
\hline Open process innovation $*$ Foreign firms & & $\begin{array}{c}-\mathbf{0 . 3 4 0} * * \\
(0.149)\end{array}$ \\
\hline Employees & $\begin{array}{c}\mathbf{0 . 0 7 4} * * * \\
(0.025)\end{array}$ & $\begin{array}{c}\mathbf{0 . 0 7 5} * * * \\
(0.025)\end{array}$ \\
\hline Directors & $\begin{array}{c}0.102 \\
(0.062)\end{array}$ & $\begin{array}{c}0.105 \\
(0.062)\end{array}$ \\
\hline Age & $\begin{array}{c}\mathbf{0 . 2 1 7} * * * * \\
(0.066)\end{array}$ & $\begin{array}{c}\mathbf{0 . 2 1 5} * * * \\
(0.066)\end{array}$ \\
\hline Negative growth & $\begin{array}{c}0.126 \\
(0.108)\end{array}$ & $\begin{array}{c}0.127 \\
(0.108)\end{array}$ \\
\hline Positive growth & $\begin{array}{c}0.106 \\
(0.081)\end{array}$ & $\begin{array}{c}0.108 \\
(0.081)\end{array}$ \\
\hline Profitable & $\begin{array}{c}0.057 \\
(0.108)\end{array}$ & $\begin{array}{c}0.052 \\
(0.108)\end{array}$ \\
\hline Intend to growth & $\begin{array}{c}\mathbf{0 . 6 6 9} * * * \\
(0.100)\end{array}$ & $\begin{array}{c}\mathbf{0 . 6 6 0} * * * \\
(0.100)\end{array}$ \\
\hline$N$ & 5142 & 5142 \\
\hline
\end{tabular}

Notes: Standard errors are in parentheses. Bold values are significant at $10 \%$ or better. ***, $* *$ and $*$ are significance level at $1 \%, 5 \%$ and $10 \%$ respectively. 